\title{
Dermatologic Surgery
}

National Cancer Institute

\section{Source}

National Cancer Institute. Dermatologic Surgery. NCI Thesaurus. Code C51559.

Surgery on the skin (integument). 